of the Society, which Mr. Eaton exhibited to the members. Among them were Daniel Defoe's "Compleat English Tradesman," and the sequel to it, "The Pleasant Art of Money-catching;" a little book on trade by Sir Walter Raleigh; and a German book on the sixteenth century with pictures and descriptions of the various trades; Defoe's "Trial of Count Tariff"; and the first book written on railroads in America, by John Stevens, of which there are only six copies known and in which, as far back as 1812 , the author prophesied that trains would be travelling from New York to Albany at sixty miles an hour. This is the best preserved copy of the six, with an autographed letter from the author. There were, besides, a book by Sir William Playfair containing the first charts ever made; and a valuable incunabulum printed in Venice in 1494, the first historical treatise on accounting.

\title{
The First Iron Works in the Colonies
}

THE Baker Library has recently come into possession of a bit of history which should be intensely interesting to a country in which iron and steel play so large a part. Fifty-five documents have been unearthed, dated between 1650 and 1685 , and relating to the Iron Works at Lynn, Massachusetts, the first in the country. Some are originals, and others are certified as true copies. It does not appear for whom these papers were collected, but as one of them has a note by the foreman of the jury who heard the trial of John Gifford, the second ill-fated agent of the "Undertakers of the Iron Works," they may have belonged to him. There are accounts, inventories, affadavits, letters and petitions of laborers for wages overdue, for the company seems to have been continually involved in financial and legal entanglements.

Massachusetts was not the first place in the country where iron was discovered. There was some found earlier in North Carolina, and after that an attempt was made to manufacture it in Virginia, but the first successful works were established in 1645 , in that part of Lynn, Massachusetts now called-Saugus. Bog iron had been discovered there much earlier, in large quantities within a mile or two of the meeting house, but it was not until 1643 that the want of iron tools and iron ware led several of the enterprising citizens of the town to make an attempt to work it. Foremost of these 


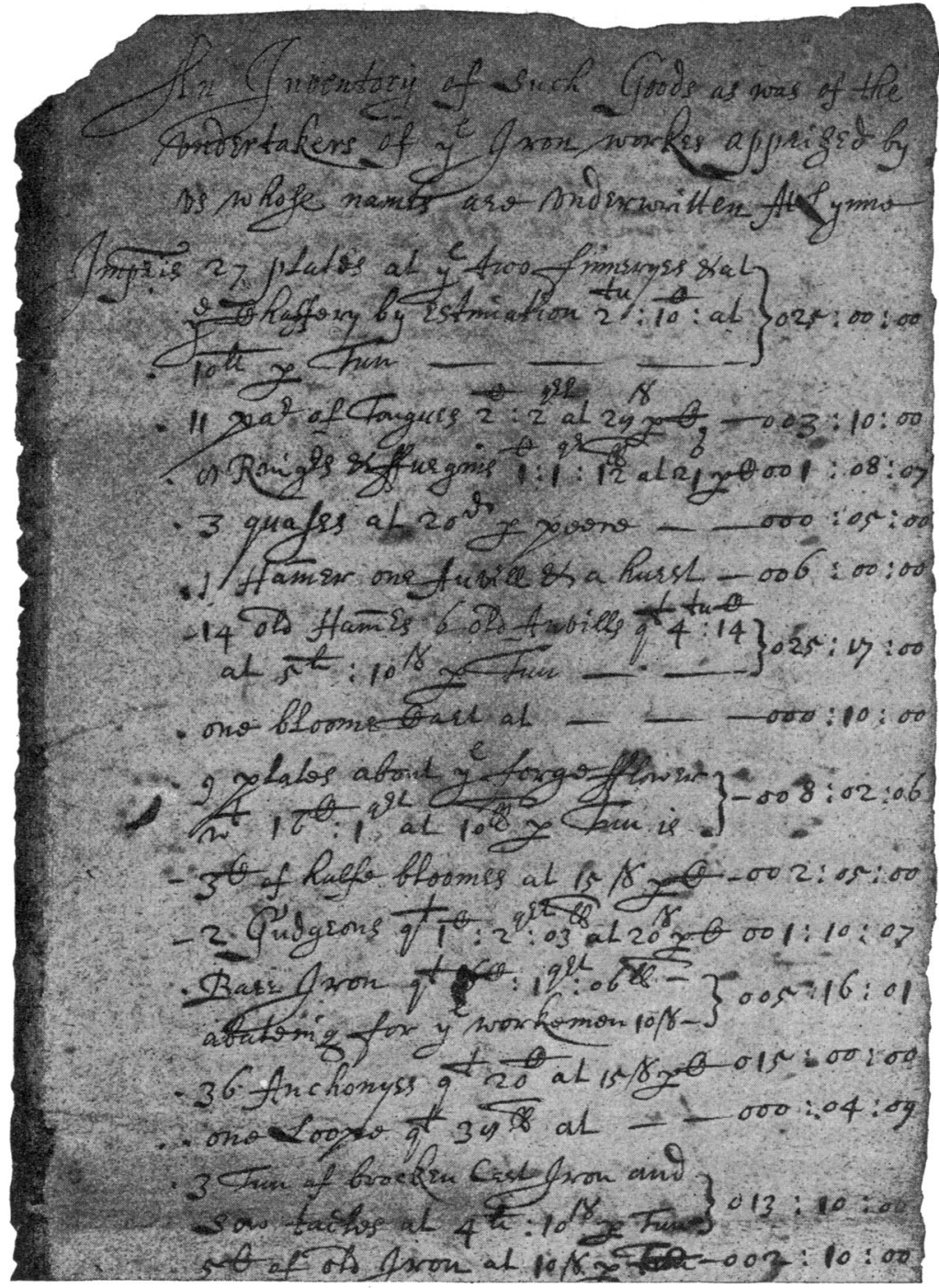

Part of an Inventory from the First I ron Works in the American Colonies 
were Thomas Dexter, an energetic person, and Robert Bridges, who was "endued with able parts, and forward to improve them to the glory of God and his people's good." In I642, the latter took some specimens of the ore to England, where he succeeded in interesting eleven men, the most prominent of whom was John Becx, and "The Company of Undertakers for the Iron Works" was formed. John Winthrop, Jr., was also connected with the enterprise, and reference to him, and to the satisfactory quality of the iron produced, appears in the correspondence between Mr. Endicott and Governor Winthrop. Articles of wrought iron, as well as castings, were manufactured, and tradition has it that oyster shells were used as a flux for the ore. The first casting made, a small pot with a cover, barely capable of containing a quart, now occupies a post of honor in the Lynn Public Library.

The General Court granted a monopoly to the Works for twentyone years, by way of encouragement, and the right to take three square miles of land at six places for its business, and it was stipulated that forges as well as smelters should be set up. Advantage was taken of this grant to establish another works at Braintree, but by the inventories at both foundries included in this collection, the new works do not appear to have been so extensive as those at Lynn. One for the latter establishment, "The Inventory of Goods as was of the Undertakers of ye Iron Works, Apprized by Us Whose Names are Underwritten at Lynn, signed, given in our hands this 4th day of November, 1653 ," gives a very good idea of the works and the material which they produced. There were twenty-seven plates, weighing two tons and ten cwt. and valued at twenty-five pounds; and eleven pair of tongs, a hammer and anvil, and a hurst valued at six pounds, besides fourteen old hammers, and six anvils. There was a lot of bar iron and thirty six anchors at twenty cwt. valued at fifteen shillings a cwt. There were also gudgeons, bellows, irons, and various kinds of scrap. They had a broad axe, and four cross-cut saws not fitted. Although exemption from "all watchings" (for Indians) was among the privileges of those connected with the Works, an entry for fourteen muskets, one halbert, tourteen pair of bandoleers and nine swords shows that they did not propose to be caught napping by the Indians.

Skilled mechanics had been brought over from England, largely from Hammersmith, which gave its name to the village at the Iron Works. Among these workmen was Joseph Jenks, a machinist of great genius, who erected the first forge in the Colonies, and 
made the dies for the pine tree shilling, besides taking out several patents for improvements in iron tools and mills. In the inventory appears another class of attaché of the Iron Works. John Adams, an indentured servant, is valued for four years at five pounds; John Flood, an English boy, is put down for six years at six pounds; and "thirty five Scots, as followeth, viz:..." are entered at $35^{\circ}$ pounds. One of several old houses, still standing near the spot, one of which did belong to Wallace Nutting, was used for the quarters of the indentured servants. Farther down the list there is an account of the money spent on the Scots; "for I I beds and bolsters with 22 coverlets and blankets among ye Scots"; six pounds, one shilling, threepence for suits for them made by Thomas Hartshorne; and "soe much paid for a case of strong waters for ye Scots and other men, 2 pounds," showing the life of an indentured servant was not without its attractions. The Scots must have been landed in Boston originally, because their transportation from thence to Lynn by boat cost the Company two shillings, sixpence; and they were fed on the way, for the next entry shows "soe much to William Edmunds for diet for the Scots by waye from Boston to ye worckes, 15 shillings tenpence." Evidently the climate did not completely agree with all of them, for Dr. Alcocke had one pound for "phisicke" and one pound, twelve shillings for cure of two Scots, and Goody Burte received fourteen shillings for "phisicke."

The lot of an agent of the Undertakers was not a happy one. Little mention is made in histories of the Iron Works of Richard Leader, the first to be sent over, until he appears arraigned by the Court in 1651 for "threatening, and in a high degree reproaching and slaundering the Courts, magistrates, and gouernment of the comon weale, and defaming the toune and church of Lynne, also afronting and reproaching the counstable in the execution of his office." All this was "spoken in the midst of the sea, going hence to England." What was the cause of Mr. Leader's displeasure with everything pertaining to the Commonwealth of Massachusetts, is left to the imagination. A letter among the manuscripts, dated from Gravesende, England, testifies that he was dismissed from the employ of the Company in 1650. His successor, John Gifford, who figures more largely in the records both of the Company and the Essex County Courts, was not destined to find the situation any easier. It was from the year of Mr. Leader's dismissal that the troubles of the Iron Works began in earnest. There were 
suits from the neighbors on account of land flowed by the dam at the works, or of the failure of the alewives to come to their " wyres," because sufficient water had not been left in the "ould river." And there grew up a fear among the colonists that the manufacture of iron would consume all the available supply of wood. John Gifford stepped into the thick of the dissatisfaction, and the history of his trials and misfortunes is indicated in the records of the Essex County Courts, and in the documents in the possession of the Society. Eventually we find him in a "perishing condition" in prison, for want of "meet supplies for his releife," on account of some litigation regarding a bond given while in England. It is cheerful to note that he did not perish on that occasion, but the Court ordered him released, in consideration of his state.

The course of events concerning the Iron Works and Mr. Gifford is hard to trace from the jumbled and fragmentary records. A suit by the creditors of the Works seems to have been hovering more or less in the background during the period covered by the documents, and one of these is a petition of some workmen who are "informed that ye said workes are likely this day to be sentenced for the payment of divers great sums wherein the peticonrs are not mentioned nor related," and they "doe most humbly beseech the Court that ye peticonrs may be paid their just dues or some order taken that they may be paid in some short time."

A series of letters dated 1653 from a Commissioner of the Company, Henry Webb, printed in the "Records and Files of the Quarterly Courts of Massachusetts," paints Gifford as the blackest of villains, who was wasting the substance of the Company and defrauding the workmen with private ventures and gross mismanagement. Webb wrote to the Company of Gifford's misdeeds at every opportunity. In one Post Script he "feares to be tedious and yrfore prays acceptance of these rude lynes, writt in hast ye ship being now ye first faire winde bound for Virginia, and so to England." In another letter he is taking advantage of a voyage of the Mayflower to let John Becx and Company know how badly things are going. But in view of the fact that Gifford was later reinstated in the full confidence of the Company, and of a later verdict of the Court for John Gifford for defamation by Henry Webb, it is probable that some personal animosity, or at best a blindly mistaken idea of the whole affair, was responsible for Webb's charges.

After Gifford had withdrawn his connection with the Company, 
its affairs continued in the same perturbed state, until at last a person hired by the neighboring landowners whose property had been injured cut away the flood gates, partly destroying the works. The lower story of a house standing at the left of the dam was flooded in the process, and when the mistress came down stairs in the morning she found a live fish flopping in her oven. The works were carried on, though on a smaller scale, for about a century after their establishment, but still so encumbered with legal difficulties that it was said of them that "instead of drawing out bars of iron for the country's use, there was hammered out nothing but contention and law suits." At present, all that remains of the original Iron Works is a series of grass-grown hillocks marking the mounds of scoria from the plant, and these old documents, with their archaic expression and penmanship and worn paper, are now in the possession of The Business Historical Society.

\section{The Wedgwood Papers}

In the museum of the Wedgwood firm at Etruria, Stoke-on-Trent, is a collection of more than a million manuscripts, the business papers of Josiah Wedgwood, founder of the firm (b. I730, d. I795). Invoices, ledgers, oven books, letters to his customers and his bankers, memoranda on the organization of his business and of the industry as a whole - there is a mass of material, incomplete and only gradually being got into order by the devoted labours of the Curator, Mr. Cook. Unfortunately no effort had been made at the time to preserve these records, which were therefore destroyed or dispersed. The story of the collection of the surviving papers by a number of admirers would have its amusing side; one enthusiastic antiquarian noticed that his butcher wrapped his meat in pages from a Wedgwood ledger, and thus discovered several sacks of old papers. The records of any business enterprise of the eighteenth century would be of great value and interest, particularly to one who was familiar with the remarkable work of that group of scholars at Manchester inspired by the late Professor Unwin. I cannot do better than quote from the preface of one of these scholars, T. S. Ashton, to his "Iron and Steel in the Industrial Revolution." 